DOI: $10.29303 / \mathrm{jrpb} . \mathrm{v} 8 \mathrm{i} 2.195$

ISSN 2301-8119, e-ISSN 2443-1354

Tersedia online di http://jrpb.unram.ac.id/

\title{
APLIKASI METODE ANALISIS SWOT UNTUK MERUMUSKAN STRATEGI PEMANFAATAN MEKANISASI PERTANIAN DI KABUPATEN KAPUAS HULU PROVINSI KALIMANTAN BARAT
}

The Application of SWOT Analysis Method for Formulating Agricultural Mechanization

Strategy in Kapuas Hulu Regency, West Kalimantan Province

\author{
Erniati $^{1}$, Mohammad Solahudin ${ }^{2}$, Panus Lulung ${ }^{3}$, Intan Kusuma Wardani ${ }^{1, *)}$ \\ ${ }^{1}$ Teknologi Mekanisasi Pertanian, Politeknik Pembangunan Pertanian Bogor \\ Jalan Aria Surialaga No 1, Bogor Barat, Bogor 16001, Indonesia \\ ${ }^{2}$ Program Pasca Sarjana, IPB University \\ Kampus IPB University Dramaga, Bogor 16680, Indonesia \\ ${ }^{3}$ Dinas Pertanian dan Pangan, Kabupaten Kapuas Hulu
}

Putussibau, Kec. Putussibau Utara, Kapuas Hulu, Kalimantan Barat 78752, Indonesia

Email*: intankusuma@pertanian.go.id

Diterima: Juli 2020

Disetujui: September 2020

\begin{abstract}
Kapuas Hulu Regency is located at the border area of Indonesia and Malaysia. This location has excellent potential for agricultural development but has not been managed optimally. Therefore, the Ministry of Agriculture seeks to develop agriculture in Kapuas Hulu Regency by increasing the number of agricultural equipment and machinery assistance to reach 293\% until 2018. This research aims to formulate a strategy for implementing agricultural mechanization based on resources, government policy, social, technology, economy, and natural resources to complete the previous research gap. The methods used are SWOT and QSPM analysis. The results showed that the optimization of cooperation with the academic field was such as involving college student in extension activities is necessary. This is required to fulfil the lack amount of extension in the Kapuas Hulu regency.
\end{abstract}

Keywords: Kapuas Hulu Regency; agricultural mechanization strategy; QSPM; SWOT

\begin{abstract}
ABSTRAK
Kabupaten Kapuas Hulu berada di wilayah perbatasan Indonesia dan Malaysia. Lokasi tersebut memiliki potensi pengembangan pertanian yang besar, tetapi belum dikelola secara optimal. Oleh karena itu, Kementerian Pertanian berupaya untuk mengembangkan pertanian di Kabupaten Kapuas Hulu dengan meningkatkan jumlah bantuan alat dan mesin pertanian yang mencapai 293\% sampai dengan 2018. Penelitian ini bertujuan untuk merumuskan strategi implementasi mekanisasi pertanian berdasarkan aspek resources, government policy, social, technology, economy, dan natural resources untuk melengkapi gap penelitian sebelumnya. Metode yang digunakan adalah analisis SWOT dan QSPM. Hasil penelitian menunjukkan bahwa diperlukan optimasi kerjasama dengan bidang akademik, seperti melibatkan mahasiswa
\end{abstract}


PKL (Praktek Kerja Lapangan) dalam kegiatan penyuluhan. Hal ini bertujuan untuk mencukupi kekurangan penyuluh di Kabupaten Kapuas Hulu.

Kata Kunci: Kabupaten Kapuas Hulu; strategi mekanisasi pertanian; QSPM; SWOT

\section{PENDAHULUAN}

\section{Latar Belakang}

Kabupaten Kapuas Hulu yang terletak berbatasan dengan Serawak (Malaysia) adalah salah satu wilayah dengan potensi pertanian yang besar. Terdapat enam kecamatan yang berbatasan langsung dengan Malaysia, terdiri dari 65 desa dan 4 kelurahan (Dinas Pertanian dan Pangan, 2019).

Menurut Pasandaran et al., (2014), permasalahan konkret untuk wilayah perbatasan di Kabupaten Kapuas Hulu terletak pada bidang ekonomi, infrastuktur, dan sumberdaya alam. Dari segi ekonomi, kondisi masyarakat di sekitar wilayah perbatasan tergolong ke dalam ekonomi rendah. Faktor utama yang mempengaruhi kondisi tersebut adalah keterbatasan akses teknologi. Adapun persentase masyarakat yang bekerja di sektor pertanian adalah sebesar $95 \%$ dan 5\% sisanya bekerja di pertambangan, industri, perdagangan, transportasi, jasa, dan sektor lainnya. Hal ini menunjukkan bahwa pertanian merupakan sektor yang potensial untuk pengembangan perekonomian penduduk di wilayah perbatasan.

Dalam rangka pengembangan pertanian melalui peningkatan produktivitas dan efisiensi usaha tani, peran mekanisasi menjadi hal yang sangat penting untuk dilakukan. Penggunaan mekanisasi pertanian dilakukan dengan tujuan meningkatkan daya kerja manusia dalam proses produksi, sehingga dapat meningkatkan efisiensi tenaga manusia. Menurut Pusat Data dan Sistem Informasi Pertanian (2018), jumlah tenaga kerja bidang pertanian cenderung menurun, yaitu 36,96 juta pada bulan 2017 menjadi 35,8 juta pada tahun 2018.

Pada tahun 2018, Kementerian Pertanian telah menyalurkan bantuan alat dan mesin pertanian (alsintan) sebanyak 370.378 unit atau naik 4,752\% dibanding tahun 2013. Sesuai dengan itu, di Kabupaten Kapuas Hulu terjadi kenaikan bantuan alsintan sejak tahun 2015-2018 sebanyak 293\% dibandingkan dengan bantuan pada tahun-tahun sebelumnya. Alsintan yang diberikan berupa traktor roda dua, traktor roda empat, pompa air, corn planter, rice transplanter, mini excavator, mini combine harvester, medium combine harvester, power trasher, dan hand sprayer (Dinas Pertanian dan Pangan, 2019; Ichniarsyah \& Erniati, 2020). Akan tetapi, adanya peningkatan bantuan tersebut ternyata belum dapat meningkatkan produktivitas pertanian di Kapuas Hulu. Salah satunya akibat bencana alam banjir pada tahun 2015 yang menurunkan produktivitas pertanian.

Menurut Susilawati (2016) dan Ichniarsyah \& Erniati (2020), ketersediaan mekanisasi pertanian di wilayah Kapuas Hulu berpengaruh pada peningkatan produktivitas pertanian, perluasan pasar, dan peningkatan pendapatan petani. Menurut Handaka \& Prabowo (2016), permasalahan mekanisasi pertanian di Indonesia sejak tahun 1950 terjadi karena munculnya premature mechanization. Permasalahan ini dapat memicu gagalnya program bantuan alsintan dari pemerintah. Oleh karena itu, program bantuan pengadaan alsintan perlu mempertimbangkan aspek teknis, ekonomis, sumberdaya manusia, sumberdaya alam, teknologi, dan sosial setempat.

Penelitian sebelumnya yang dilakukan oleh Aldillah (2016), Tarigan (2019), Wijaya, et al. (2018) membahas tentang pengembangan implementasi mekanisasi pertanian melalui metode review ilmiah dan analisis deskriptif. Penelitian dengan analisis tersebut sangat bergantung pada 
kemampuan penulis dalam literature review.

Strengths, Weaknesses, Opportunities, and Threats (SWOT) Analysis merupakan analisis yang mengintegrasikan antara kondisi internal dan eksternal yang mempengaruhi kinerja organisasi. Matriks SWOT didasarkan pada logika stakeholders. Identifikasi kondisi internal dan eksternal tersebut berdasarkan pada pembobotan dinilai dari tingkat kepentingannya. Pada tahap penyusunan strategi, selanjutnya diperlukan analisis tambahan yang mampu menghasilkan strategi yang bersifat komprehensif dan tersusun secara sistematis.

Analisis lanjutan berupa Quantitative Strategic Planning Matriks (QSPM) adalah salah satu metode yang dapat digunakan untuk mengurangi subjektivitas pembobotan pada metode SWOT. Metode QSPM dapat menentukan alternatif strategi terbaik berdasarkan nilai total terbesar (Nisak, 2013; Rangkuti, 2005; Setyorini \& Santoso, 2017; Hashemi, et al., 2011; Putri, et al., 2014; Ichniarsyah \& Erniati, 2020); Wardani \& Erniati, 2020).

\section{Tujuan}

Penelitian ini bertujuan untuk memenuhi gap penelitian sebelumnya dengan melakukan kajian tentang perumusan strategi implementasi mekanisasi, khususnya di Kabupaten Kapuas Hulu dengan metode SWOT dan QSPM.

\section{METODE PENELITIAN}

\section{Bahan}

Data primer pada penelitian ini didapatkan dari penyebaran kuesioner. Selain itu, penelitian ini juga menggunakan data sekunder yang meliputi data statistik dari instansi terkait mekanisasi pertanian (Kabupaten Kapuas Hulu dalam Angka serta Laporan Dinas Pertanian dan Pangan Provinsi Kabupaten Kapuas Hulu Tahun 2018).

Penyusunan indikator-indikator pada faktor internal dan eksternal melibatkan pihak pengelola mekanisasi di Kabupaten Kapuas Hulu. Faktor yang dievaluasi dalam interview adalah sebagai berikut:

1. Faktor internal mencakup human resources, government policy, social, technology, economy, dan natural resources.

2. Faktor eksternal mencakup government policy, technology, natural resources, dan economy.

\section{Tahapan penelitian}

Penelitian ini terdiri dari beberapa tahap, meliputi:

1. Identifikasi masalah melalui wawancara langsung dengan pihak Dinas Pertanian dan Pangan. Kegiatan penelitian ini terintegrasi dengan Praktek Kerja Lapangan (PKL) mahasiswa Politeknik Pembangunan Pertanian Bogor yang berlokasi di Kabupaten Kapuas Hulu.

2. Penentuan variabel penelitian berdasarkan research gap dari penelitian sebelumnya. Peneliti bersama dengan pemangku kebijakan terkait di tingkat kabupaten merumuskan variabel penelitian yang sesuai dengan kondisi aktual implementasi mekanisasi pertanian di Kabupaten Kapuas Hulu.

3. Responden penelitian adalah Kepala Dinas/Pejabat yang menangani mekanisasi pertanian di Dinas Pertanian dan Pangan Kabupaten Kapuas Hulu, Penyuluh Pertanian Lapangan (PPL), dan petani yang tersebar di 25 desa lokasi PKL di Kabupaten Kapuas Hulu. Responden tersebut merupakan pelaku langsung yang mengetahui kondisi implementasi mekanisasi pertanian di Kabupaten Kapuas Hulu.

4. Pengujian validitas kuesioner dilakukan dengan cara melibatkan beberapa ahli meliputi dosen dari IPB University dan Politeknik Pembangunan Pertanian Bogor yang memahami tentang mekanisasi pertanian. Uji validitas bertujuan untuk menilai relevansi kuesioner terhadap studi yang dilaksanakan. 
5. Analisis SWOT dan QSPM terdiri dari empat tahapan analisis yang meliputi (Setyorini \& Santoso, 2017):

a. Tahap pemasukan faktor internal dan eksternal ke dalam tabel Internal Factor Analysis Strategy (IFAS) dan Eksternal Factor Analysis Strategy (EFAS). Pertama, identifikasi faktor internal dan eksternal dilakukan oleh Kepala Dinas atau Pejabat yang menangani mekanisasi pertanian di Dinas Pertanian dan Pangan Kabupaten Kapuas Hulu dan peneliti. Kedua, pembobotan dilakukan oleh responden penelitian pada kuesioner. Ketiga, penentuan rating berdasarkan tingkat urgensi dengan ketentuan sebagai berikut:

1) nilai 4 apabila Dinas Pertanian dan Pangan Kabupaten Kapuas Hulu mampu memanfaatkan faktor peluang sangat baik dan ancaman sangat lemah;

2) nilai 3 apabila Dinas Pertanian dan Pangan Kabupaten Kapuas Hulu mampu memanfaatkan faktor peluang baik dan ancaman lemah;

3) nilai 2 apabila Dinas Pertanian dan Pangan Kabupaten Kapuas Hulu mampu memanfaatkan faktor peluang cukup baik dan ancaman kuat; dan

4) nilai 1 apabila Dinas Pertanian dan Pangan Kabupaten Kapuas Hulu tidak mampu memanfaatkan faktor peluang baik dan ancaman tinggi.

b. Perkalian bobot dan rating

Bobot didapatkan dari hasil analisis data kuesioner. Bobot tertimbang untuk masing-masing strengths, weaknesses, opportunities, dan threats berjumlah satu. Skor diperoleh dengan cara mengkalikan bobot dan rating.

c. Tahap pencocokan
1) Matriks IFAS internal yaitu strength dan

weakness.

2) Matriks EFAS berisi faktor eksternal opportunity dan threat.

d. Matriks SWOT berfungsi sebagai alat untuk menyusun alternatif strategi berdasarkan pola sebagai berikut: i) mengoptimalkan kekuatan untuk memanfaatkan peluang (SO), ii) meminimalisir dampak dari kelemahan internal dengan cara memanfaatkan kesempatan eksternal (WO), iii) menggunakan kekuatan untuk meminimalisir ancaman (ST), dan iv) mencocokkan kelemahan dan ancaman (WT).

e. Tahap pengambilan keputusan menggunakan QSPM. Analisis ini berfungsi untuk meminimalisir subjektifitas penilaian dari responden. Tahapan analisis QSPM sebagai berikut:

1) memasukan faktor internal dan eksternal dari matriks IFAS dan EFAS;

2) memasukan bobot faktor internal dan eksternal sesuai matriks IFAS dan EFAS;

3) menentukan angka daya tarik dari masing-masing strategi tersebut nilai 1 (tidak menarik), 2 (agak menarik), 3 (cukup menarik), dan 4 (sangat menarik); dan

4) menghitung nilai Total Attractive Score dengan mengkalikan bobot dan nilai daya tarik.

\section{HASIL DAN PEMBAHASAN}

Analisis SWOT dan QSPM telah digunakan untuk menyusun alternatif manajemen strategi untuk mengembangkan mekanisasi pertanian di Kabupaten Kapuas Hulu. Berdasarkan hasil penelitian yang melibatkan stakeholders meliputi pemangku kebijakan dan pengguna mekanisasi pertanian bantuan dari pemerintah, Implementasi mekanisasi pertanian di Kabupaten Kapuas Hulu ternyata 
dipengaruhi oleh beberapa faktor internal dan eksternal.

\section{a. Analisis faktor internal}

Analisis faktor internal bertujuan untuk mengidentifikasi kekuatan dan kelemahan Dinas Pertanian dan Pangan Kabupaten Kapuas Hulu dalam upaya mendukung peningkatan produksi pangan melalui strategi mekanisasi pertanian. Faktor internal mencakup human resources, government policy, social, technology, economy, dan natural resources. Variabel kekuatan dan kelemahan faktor internal tersebut ditunjukkan pada Tabel 1 dan Tabel 2.

Tabel 1. Kekuatan (Strenght/S)

\begin{tabular}{|c|c|c|}
\hline No & Strength (S) & Uraian \\
\hline 1 & Human resources: Capacity building & $\begin{array}{l}\text { Perwakilan anggota kelompok tani } \text { telah } \\
\text { mendapatkan pelatihan operator pengolahan tanah } \\
\text { dan pelatihan pertanian secara umum }\end{array}$ \\
\hline 2 & $\begin{array}{l}\text { Human resources: Provide training } \\
\text { to the farmers }\end{array}$ & $\begin{array}{l}\text { Dinas Pertanian dan Pangan telah } \\
\text { menyelenggarakan pelatihan bagi petani terkait } \\
\text { materi pertanian secara umum dan pelatihan operator } \\
\text { bagi perwakilan anggota yang menerima bantuan } \\
\text { alsintan }\end{array}$ \\
\hline 3 & $\begin{array}{l}\text { Government policy: Relationship } \\
\text { between scientists and extension } \\
\text { personnel }\end{array}$ & $\begin{array}{l}\text { Para penyuluh menjalin hubungan dengan dosen- } \\
\text { dosen Perguruan Tinggi dan BPTP Provinsi }\end{array}$ \\
\hline 4 & $\begin{array}{l}\text { Government policy: Good } \\
\text { agriculture extension network }\end{array}$ & $\begin{array}{l}\text { Jaringan penyuluh sangat baik sehingga } \\
\text { memudahkan komunikasi pada daerah yang } \\
\text { memiliki keterbatasan dalam jaringan komunikasi }\end{array}$ \\
\hline 5 & Social: Social barrier for women & Hambatan sosial untuk perempuan hampir tidak ada \\
\hline 6 & $\begin{array}{l}\text { Human resources: Hard working } \\
\text { farmer }\end{array}$ & $\begin{array}{l}\text { Petani bekerja keras dengan medan yang cukup sulit } \\
\text { (lokasi pertanian cukup jauh dari pemukiman/lokasi } \\
\text { pertanian berbukit) }\end{array}$ \\
\hline 7 & $\begin{array}{l}\text { Human resources: Increase of } \\
\text { farmer's knowledge }\end{array}$ & $\begin{array}{l}\text { Terjadi peningkatan pengetahuan petani, baik untuk } \\
\text { manajemen lahan }\end{array}$ \\
\hline 8 & $\begin{array}{l}\text { Human resources: Farmers training } \\
\text { on pest and diseases }\end{array}$ & $\begin{array}{l}\text { Petani mendapat pelatihan tentang hama dan } \\
\text { penyakit dari penyuluh }\end{array}$ \\
\hline 9 & $\begin{array}{l}\text { Natural resources: Land potential to } \\
\text { agriculture }\end{array}$ & $\begin{array}{l}\text { Masih banyak lahan yang berpotensi untuk pertanian } \\
\text { yang belum dimanfaatkan, karena lahan pertanian } \\
\text { baru mencapai } 1,21 \% \text { dari total luas Kabupaten } \\
\text { Kapuas Hulu, sehingga sangat memungkinkan } \\
\text { adanya pengembangan lahan pertanian }\end{array}$ \\
\hline
\end{tabular}

Tabel 2. Kelemahan (Weakness/W)

\begin{tabular}{ll}
\hline No & \multicolumn{1}{c}{ Weakness $(\mathbf{W})$} \\
\hline 1 & $\begin{array}{l}\text { Human resources: Use of rural youth } \\
\text { for dissemination }\end{array}$
\end{tabular}

2 Human resources: Populations

Jumlah pemuda yang mampu melakukan diseminasi tentang pertanian masih sedikit, padahal keberadaan pemuda menjadi daya tarik masyarakat untuk melakukan usaha tani

\section{2 . Human resources: Populations}

3 Human resources: Indigenous knowledge

Jumlah penduduk Kabupaten Kapuas Hulu. 258,984 ribu dengan luas lahan pertanian $2.589 .898 \mathrm{Ha}$ meliputi lahan sawah dan non-sawah

Pengetahuan asli masyarakat adalah pengetahuan turun temurun yang belum mengenal teknologi, salah satunya ladang berpindah

$4 \quad$ Human resources: Lack of extension Belum semua desa memiliki penyuluh seperti yang worker

diamanatkan dalam Undang-Undang 


\begin{tabular}{|c|c|c|}
\hline No & Weakness (W) & Uraian \\
\hline & & $\begin{array}{l}\text { Perlindungan dan Pemberdayaan Petani No 19/2013 } \\
\text { (1 desa } 1 \text { penyuluh) }\end{array}$ \\
\hline 5 & $\begin{array}{l}\text { Human resources: High young }>30 \\
\text { population }\end{array}$ & $\begin{array}{l}\text { Jumlah petani muda sangat sedikit, kurang lebih } \\
10 \%\end{array}$ \\
\hline 6 & Technology: Appropriate technology & $\begin{array}{l}\text { Teknologi tepat guna belum maksimal, karena baru } \\
\text { sampai tahap penggunaan alsintan pada budidaya } \\
\text { pertanian }\end{array}$ \\
\hline 7 & Human resources: Illiterate farmers & $\begin{array}{l}\text { Pendidikan masih sangat rendah, yaitu SD atau tidak } \\
\text { tamat SD }\end{array}$ \\
\hline 8 & $\begin{array}{l}\text { Human resources: Increase of farmer's } \\
\text { knowledge }\end{array}$ & $\begin{array}{l}\text { Peningkatan pengetahuan petani masih sangat } \\
\text { minim, yaitu hanya dilakukan oleh penyuluh }\end{array}$ \\
\hline 9 & $\begin{array}{l}\text { Human resources: Lack of knowledge } \\
\text { about value addition }\end{array}$ & $\begin{array}{l}\text { Masih kurangnya pengetahuan tentang penambahan } \\
\text { nilai }\end{array}$ \\
\hline 10 & $\begin{array}{l}\text { Human resources: Lack of knowledge } \\
\text { on post-harvest processing }\end{array}$ & $\begin{array}{l}\text { Kurangnya pengetahuan tentang pasca panen, } \\
\text { namun untuk hasil perkebunan di wilayah tertentu } \\
\text { sudah mulai dilakukan penanganan pasca panen }\end{array}$ \\
\hline 11 & $\begin{array}{l}\text { Economy: No sufficient fund for } \\
\text { research and extension }\end{array}$ & $\begin{array}{l}\text { Anggaran yang tersedia terbatas untuk mengadakan } \\
\text { penyuluhan }\end{array}$ \\
\hline
\end{tabular}

\section{b. Analisis faktor eksternal}

Penelitian ini juga mengidentifikasi faktor eksternal yang berpengaruh pada implementasi mekanisasi pertanian mencakup human resources, government policy, technology, economy, dan natural resources. Faktor eksternal terdiri dari peluang dan ancaman yang ditunjukkan pada Tabel 3 dan Tabel 4 .

Tabel 3. Peluang (Opportunity/O)

\begin{tabular}{|c|c|c|}
\hline No & Opportunity $(O)$ & Uraian \\
\hline 1 & $\begin{array}{l}\text { Human resources: Higher } \\
\text { education/training may be given } \\
\text { in partnership with } \\
\text { university/institutes }\end{array}$ & $\begin{array}{l}\text { Adanya Praktek Kerja Lapang (PKL) dari Perguruan } \\
\text { Tinggi, antara lain: Polbangtan Bogor pada tahun 2017- } \\
\text { 2019; IPDN Propinsi Kalimantan Barat tahun 2018; } \\
\text { IAIN/STAIN Kabupaten Kapuas Hulu setiap tahun; } \\
\text { adanya penelitian dari mahasiswa IPB University antara } \\
\text { lain dari prodi PSL (Pengelolaan Sumberdaya Alam dan } \\
\text { Lingkungan) }\end{array}$ \\
\hline 2 & $\begin{array}{l}\text { Government policy: Favorable } \\
\text { government policy for the farmers }\end{array}$ & $\begin{array}{l}\text { Kebijakan Dinas Kabupaten: menyusun permohonan } \\
\text { bantuan alsintan dan memfasilitasi transportasi alsintan } \\
\text { sampai lokasi }\end{array}$ \\
\hline 3 & $\begin{array}{l}\text { Government policy: Large } \\
\text { research network with skilled } \\
\text { manpower }\end{array}$ & $\begin{array}{l}\text { Masih banyak potensi yang bisa diteliti, tetapi lokasi yang } \\
\text { cukup jauh membuat tidak banyak peneliti yang } \\
\text { melakukan penelitian di kabupaten tersebut }\end{array}$ \\
\hline 4 & $\begin{array}{l}\text { Government policy: Crop } \\
\text { insurance for farmer }\end{array}$ & $\begin{array}{l}\text { Petani belum teredukasi dengan adanya Program } \\
\text { Asuransi Usaha Tani Padi (AUTP). UU } 19 \text { tahun } 2013 \\
\text { pasal } 37 \text { ayat (1) menyebutkan bahwa Pemerintah dan } \\
\text { Pemerintah Daerah sesuai dengan kewenangannya } \\
\text { berkewajiban melindungi usaha tani yang dilakukan oleh } \\
\text { petani dalam bentuk asuransi pertanian. Sesuai Peraturan } \\
\text { Menteri Pertanian No. } 40 \text { Tahun 2015, sebagian premi } \\
\text { asuransi pertanian akan ditanggung oleh pemerintah } \\
\text { Indonesia. Pada tahun 2019, sosialisasi asuransi pertanian } \\
\text { telah dilakukan oleh PT. Asuransi Sinar Mas dalam } \\
\text { bentuk CSR (Corporate Social Responsibility). }\end{array}$ \\
\hline
\end{tabular}




\begin{tabular}{clll}
\hline No & \multicolumn{1}{c}{ Opportunity $(\boldsymbol{O})$} & \multicolumn{3}{c}{ Uraian } \\
\hline 5 & $\begin{array}{l}\text { Technology: Use of modern } \\
\text { agriculture engineering tools or } \\
\text { implements }\end{array}$ & $\begin{array}{l}\text { Adanya bantuan alat dan mesin pertanian meningkatkan } \\
\text { pengetahuan petani, sehingga petani mampu } \\
\text { memanfatkan alat mesin pertanian dan } \\
\text { mengiplementasikannya }\end{array}$ & \\
\hline
\end{tabular}

Tabel 4. Ancaman (Threat/T)

\begin{tabular}{|c|c|c|}
\hline No & Threat (T) & Uraian \\
\hline 1. & Human resources & $\begin{array}{l}\text { Komunikasi dengan pihak luar Kabupaten masih } \\
\text { terkendala bahasa. Walaupun banyak petani yang } \\
\text { mengerti bahasa Indonesia }\end{array}$ \\
\hline 2. & Natural resources & $\begin{array}{l}\text { Bencana yang sering terjadi adalah banjir pada musim } \\
\text { penghujan, akibat luapan sungai Kapuas Hulu } \\
\text { Sedangkan pada musim kemarau terjadi kekeringan } \\
\text { karena tidak ada embung }\end{array}$ \\
\hline 3. & $\begin{array}{l}\text { Natural Resources: Continuous } \\
\text { degradation of soil }\end{array}$ & $\begin{array}{l}\text { Terjadi degradasi kesuburan tanah karena tidak } \\
\text { menerapkan pertanian berkelanjutan }\end{array}$ \\
\hline 4. & Economy: Lack of sufficient funds & $\begin{array}{l}\text { Alokasi anggaran pada APBD (Anggaran Pendapatan } \\
\text { dan Belanja Daerah) untuk bidang pertanian belum } \\
\text { memadai }\end{array}$ \\
\hline
\end{tabular}

Hasil identifikasi dari faktor internal dan eksternal berdasarkan survei tersebut dijadikan dasar dalam penyusunan matriks IFAS dan EFAS. Dalam penelitian ini dipilih stakeholder yang terlibat langsung dalam implementasi mekanisasi di Kabupaten Kapuas Hulu. Dalam hal ini expert judgment adalah pegawai pemerintahan meliputi Kepala Dinas/Pejabat yang menangani mekanisasi pertanian di Dinas Pertanian dan Pangan serta PPL (Penyuluh Pertanian Lapangan) di Kabupaten Kapuas Hulu. Selain itu, evaluasi juga dilakukan berdasarkan hasil kuesioner dari petani penerima bantuan mekanisasi yang tersebar pada 25 desa di Kabupaten Kapuas Hulu. Alasan pemilihan responden tersebut adalah agar penelitian yang dilakukan dapat menghasilkan gambaran yang komprehensif terkait implementasi mekanisasi di Kabupaten Kapuas Hulu.

Penentuan rating didasarkan pertimbangan ahli dengan cara pendekatan yang bersifat intuitif untuk mengorganisasikan ide atau pemikiran. Rating diperoleh dari hasil rata-rata penentuan rangking dari responden. Pada faktor internal, rating kekuatan memiliki rentang 3-4, sedangkan pada kelemahan memiliki rentang 2-4. Pada faktor eksternal rata-rata peluang memiliki rating 3-4, sedangkan ancaman berkisar 2-3. Rating dikalikan dengan bobot untuk menentukan skor pada tahap analisis menggunakan matriks IFAS dan EFAS (Tabel 5 dan Tabel $6)$.

Tabel 5. Matriks IFAS

\begin{tabular}{|c|c|c|c|c|}
\hline \multirow{2}{*}{ SWOT } & \multirow{2}{*}{ Indikator } & \multicolumn{2}{|c|}{ Rata-rata } & \multirow{2}{*}{ Skor } \\
\hline & & Bobot & Rating & \\
\hline \multirow{9}{*}{$S$} & Internal & & & \\
\hline & 1. Pelatihan untuk operator & 0,11 & 3,00 & 0,33 \\
\hline & 2. Pelatihan tentang sistem pertanian secara umum & 0,11 & 3,00 & 0,33 \\
\hline & 3. Hubungan antara petugas dinas dan akademisi baik & 0,11 & 3,00 & 0,33 \\
\hline & 4. Hubungan antara petugas dan BPTP Provinsi baik & 0,11 & 4,00 & 0,44 \\
\hline & 5. Hubungan antara penyuluh baik & 0,11 & $\mathbf{3 , 0 0}$ & 0,33 \\
\hline & 6. Tidak ada hambatan sosial bagi perempuan & 0,11 & 4,00 & 0,44 \\
\hline & 7. Petani bersemangat dalam melakukan pekerjaan & 0,11 & 4,00 & 0,44 \\
\hline & 8. Pelatihan tentang manajemen pertanian & 0,11 & 3,00 & 0,33 \\
\hline
\end{tabular}




\begin{tabular}{clccc}
\hline \hline \multirow{2}{*}{ SWOT } & \multicolumn{1}{c}{ Indikator } & \multicolumn{2}{c}{ Rata-rata } & Skor \\
& & & Bobot & Rating \\
\hline & 9. Lahan potensial untuk pertanian luas & 0,11 & $\mathbf{4 , 0 0}$ & 0,44 \\
$\boldsymbol{N}$ & & $\mathbf{1}$ & $\mathbf{3 , 4 4}$ \\
& 1. Diseminasi oleh pemuda rendah & 0,09 & $\mathbf{4 , 0 0}$ & 0,36 \\
& 2. Regenerasi petani rendah & 0,09 & $\mathbf{3 , 0 0}$ & 0,27 \\
3. Penguasaan teknologi rendah & 0,09 & $\mathbf{2 , 0 0}$ & 0,18 \\
& 4. Jumlah penyuluh kurang & 0,09 & $\mathbf{3 , 0 0}$ & 0,27 \\
& 5. Petani muda $<10 \%$ & 0,09 & $\mathbf{3 , 0 0}$ & 0,27 \\
6. Pengenalan teknologi tepat guna masih rendah & 0,09 & $\mathbf{2 , 0 0}$ & 0,18 \\
7. Tingkat pendidikan petani SD & 0,09 & $\mathbf{2 , 0 0}$ & 0,18 \\
8. Kemandirian petani dalam belajar rendah & 0,09 & $\mathbf{3 , 0 0}$ & 0,27 \\
9. Kurang pengetahuan tentang penambahan nilai & 0,09 & $\mathbf{3 , 0 0}$ & 0,27 \\
10. Kurang pengetahuan tentang pasca panen & 0,09 & $\mathbf{2 , 0 0}$ & 0,18 \\
11. Ketersediaan dana untuk penyuluhan rendah & 0,09 & $\mathbf{3 , 0 0}$ & 0,27 \\
\hline
\end{tabular}

Tabel 6. Matriks EFAS

\begin{tabular}{clccc}
\hline \multirow{2}{*}{ SWOT } & \multicolumn{1}{c}{ Indikator } & \multicolumn{2}{c}{ Rata-rata } & Skor \\
& & & & \\
& & Bobot & Rating & \\
\hline \multirow{2}{*}{$\boldsymbol{O}$} & Eksternal & 0,2 & $\mathbf{4}$ & 0,8 \\
& 1.Adanya kegiatan PKL dari perguruan tinggi & 0,2 & $\mathbf{3}$ & 0,6 \\
& 2. Dinas setempat mengusulkan permohonan hibah alsintan & 0,2 & $\mathbf{4}$ & 0,8 \\
& 3. Kerjasama penelitian dengan perguruan tinggi & 0,2 & $\mathbf{3}$ & 0,6 \\
& 4. Asuransi usaha tani padi & 0,2 & $\mathbf{4}$ & 0,8 \\
5. Adanya hibah alsintan & & & $\mathbf{3 , 6}$ \\
& & 0,25 & $\mathbf{2}$ & 0,5 \\
$\boldsymbol{T}$ & 1. Kendala bahasa komunikasi & 0,25 & $\mathbf{2}$ & 0,5 \\
& 2. Bencana alam & 0,25 & $\mathbf{3}$ & 0,75 \\
3. Kesuburan tanah menurun & 0,25 & $\mathbf{3}$ & 0,75 \\
& 4. Dana APBD untuk pertanian tidak memadai & & & $\mathbf{2 , 5}$ \\
\hline
\end{tabular}

Alternatif strategi selanjutnya disusun pada matriks SWOT. Susunan tersebut dirumuskan oleh pemangku kebijakan bersama dengan peneliti. Adapun rumusan strategi peningkatan implementasi mekanisasi pertanian di Kabupaten Kapuas Hulu sebagai berikut:

1. Strategi SO

a. Dinas Pertanian dan Pangan Kabupaten Kapuas Hulu bekerjasama dengan instansi terkait lain untuk meningkatkan jumlah penyuluhan terkait mekanisasi pertanian. Salah satunya melalui kegiatan PKL dari perguruan tinggi.

b. Penyuluhan terkait asuransi pertanian perlu dilakukan untuk mengedukasi petani tentang program pemerintah yang bisa dimanfaatkan untuk mengantisipasi kegagalan panen sesuai dengan aturan berlaku.

\section{Strategi WO}

a. Memanfaatkan peluang kerjasama dengan perguruan tinggi untuk melakukan penyuluhan di bidang mekanisasi pertanian. Mahasiswa dan pegawai dinas terkait dapat menyusun program sesuai dengan kebutuhan pelatihan dari petani.

b. Dinas Pertanian dan Pangan Kabupaten Kapuas Hulu melaksanakan penelitian bersama dengan Politeknik Pembangunan Pertanian Bogor dan 
PengkajianTeknologi Pertanian (BPTP)

Provinsi untuk menyusun model penyuluhan dengan tujuan meningkatkan minat generasi muda untuk bertani. Salah satu langkah yang dapat dilakukan adalah melalui pendekatan mekanisasi dan teknologi pertanian.

3. Strategi ST

a. Dinas Pertanian dan Pangan Kabupaten Kapuas Hulu melaksanakan penyuluhan tentang mitigasi dan antisipasi bencana alam di bidang pertanian melalui pengaturan waktu tanam.

b. Operator yang sudah dilatih diberikan penyuluhan tambahan terkait prosedur peningkatan kesuburan lahan.
4. Strategi WT
a. Peningkatan APBD untuk bidang pertanian.
b. Penambahan jumlah penyuluh atau penyuluh swadaya.

\section{Qualitative Strategy Planning Matrix (QSPM)}

Tahapan akhir dari analisis penelitian ini adalah memilih strategi yang paling sesuai untuk diterapkan di Kabupaten Kapuas Hulu. Beberapa alternatif strategi dari matriks SWOT dinilai oleh pakar dari Kepala Dinas/Pejabat yang menangani mekanisasi pertanian di Dinas Pertanian dan Pangan Kabupaten Kapuas Hulu. Rata-rata dari nilai pakar tersebut dikalikan dengan nilai masing-masing faktor di matriks IFAS dan EFAS. Hasil analisis QSPM disajikan pada Tabel 7.

Tabel 7. Hasil analisis QSPM

\begin{tabular}{|c|c|c|c|}
\hline No. & Alternatif Strategi & Total & Peringkat \\
\hline 1. & $\begin{array}{l}\text { Dinas Pertanian dan Pangan Kabupaten Kapuas Hulu } \\
\text { bekerjasama dengan BPTP Provinsi untuk meningkatkan jumlah } \\
\text { pelatihan atau penyuluhan tentang mekanisasi pertanian }\end{array}$ & 0,6 & II \\
\hline 2. & $\begin{array}{l}\text { Penyuluhan terkait asuransi pertanian untuk mengedukasi petani } \\
\text { tentang program pemerintah yang bisa dimanfaatkan untuk } \\
\text { mengantisipasi kegagalan panen sesuai dengan aturan yang } \\
\text { berlaku }\end{array}$ & 0,4 & IV \\
\hline 3. & $\begin{array}{l}\text { Mahasiswa PKL dan pegawai dinas terkait menyusun program } \\
\text { sesuai dengan kebutuhan pelatihan petani. Salah satunya tentang } \\
\text { pemeliharaan dan perbaikan alsintan }\end{array}$ & 0,8 & I \\
\hline 4. & $\begin{array}{l}\text { Dinas Pertanian dan Pangan Kabupaten Kapuas Hulu } \\
\text { melaksanakan penelitian bersama dengan Politeknik } \\
\text { Pembangunan Pertanian Bogor dan BPTP Provinsi untuk } \\
\text { menyusun model penyuluhan untuk meningkatkan minat } \\
\text { generasi muda untuk bertani. Salah satunya melalui pendekatan } \\
\text { mekanisasi dan teknologi pertanian }\end{array}$ & 0,27 & VI \\
\hline 5. & $\begin{array}{l}\text { Dinas Pertanian dan Pangan Kabupaten Kapuas Hulu } \\
\text { melaksanakan penyuluhan tentang mitigasi dan antisipasi } \\
\text { bencana alam di bidang pertanian melalui pengaturan waktu } \\
\text { tanam }\end{array}$ & 0,25 & VIIa \\
\hline 6. & $\begin{array}{l}\text { Operator yang sudah dilatih diberikan penyuluhan tambahan } \\
\text { terkait prosedur peningkatan kesuburan lahan }\end{array}$ & 0,25 & VIIb \\
\hline 7. & Peningkatan APBD untuk bidang pertanian & 0,5 & III \\
\hline 8. & Penambahan jumlah penyuluh atau penyuluh swadaya & 0,36 & $\mathrm{~V}$ \\
\hline
\end{tabular}

Analisis QSPM menunjukkan bahwa strategi utama yang perlu dilakukan adalah penambahan jumlah penyuluh. Ketersediaan penyuluh yang memadai merupakan ujung tombak pembangunan pertanian di tingkat daerah. Menurut Moordiani, et al (2018), penyuluh memiliki peran sentral menjadi pelatih dan fasilitator kegiatan pertanian. Keberhasilan program pemerintah tergantung pada jumlah ketersediaan 
penyuluh pertanian. Hal ini sejalan dengan penilaian pakar, yaitu keterbatasan dana APBD serta kekurangan jumlah penyuluh merupakan permasalahan dalam implementasi mekanisasi pertanian di Kabupatan Kapuas Hulu. Tersedianya sumberdaya manusia tambahan dari mahasiswa PKL dapat menjadi solusi yang tepat bagi permasalahan tersebut.

\section{KESIMPULAN DAN SARAN}

\section{Kesimpulan}

Implementasi mekanisasi pertanian perlu didekati dari beberapa aspek seperti resources, government policy, social, technology, economy, dan natural resources. Hasil analisis SWOT dan QSPM menunjukkan bahwa stratagi pertama, yaitu peningkatan implementasi mekanisasi di Kabupaten Kapuas Hulu perlu melibatkan mahasiswa PKL untuk menyusun dan melaksanakan kegiatan penyuluhan sesuai kebutuhan petani terkait pemeliharaan dan perbaikan alsintan. Kedua, Dinas Pertanian dan Pangan Kabupaten Kapuas Hulu dapat bekerjasama dengan BPTP Provinsi untuk melaksanakan penyuluhan terkait mekanisasi pertanian. Ketiga, peningkatan APBD di bidang pertanian harus dilakukan. Keempat, diperlukan penyuluhan terkait Asuransi Usaha Tani Padi (AUTP). Kelima, diperlukan penambahan jumlah penyuluh atau penyuluh swadaya. Keenam, diperlukan penelitian untuk menghasilkan metode pembelajaran yang sesuai untuk generasi muda. Ketujuh, Dinas Pertanian dan Pangan Kabupaten Kapuas Hulu dapat melaksanakan penyuluhan terkait mitigasi dan antisipasi bencana terhadap potensi gagal panen. Terakhir, strategi peningkatan kesuburan lahan perlu dilakukan.

\section{Saran}

Karena penelitian dilaksanakan di wilayah perbatasan Indonesia, terdapat perbedaan lingkungan geografis yang mungkin berpengaruh pada kondisi sosial budaya masyarakat petani. Oleh karena itu, kajian lebih lanjut tentang perumusan strategi implementasi mekanisasi pertanian di wilayah lain berpeluang untuk dilakukan. Kedua, penelitian ini masih terbatas pada aspek technique, human resources, economy, government policy, dan social. Sehingga, penelitian lanjutan dengan aspek yang lebih komprehensif perlu dilakukan.

\section{UCAPAN TERIMA KASIH}

Terimakasih kepada Kementerian Pertanian, Politeknik Pembangunan Pertanian Bogor, IPB University, Dinas Pertanian dan Pangan Kabupaten Kapuas Hulu, serta mahasiswa Politeknik Pembangunan Pertanian Bogor yang sudah berkontribusi pada penelitian ini.

\section{DAFTAR REFERENSI}

Aldillah, R. (2016). Kinerja Pemanfaatan Mekanisasi Pertanian dan Implikasinya dalam Upaya Percepatan Produksi Pangan di Indonesia. In Forum penelitian Agro Ekonomi 34(2): 163-171.

Badan Pusat Statistik Kabupaten Kapuas Hulu. (2019). Kabupaten Kapuas Hulu dalam Angka. BPS Kabupaten Kapuas Hulu.

Dinas Pertanian dan Pangan. (2019). Laporan Dinas Pertanian dan Pangan Provinsi Kabupaten Kapuas Hulu Tahun 2018.

Handaka, \& Prabowo, A. (2016). Kebijakan Antisipatif Pengembangan Mekanisasi Pertanian. Analisis Kebijakan Pertanian, 11(1): 27-44.

Hashemi, N. F., Mazdeh, M. M., Razeghi, A., \& Rahimian, A. (2011). Formulating and Choosing Strategies using SWOT Analysis and QSPM Matrix: A Case Study of Hamadan Glass Company. In 
Proceedings of the $41^{\text {st }}$ International

Conference on Computers \& Industrial Engineering, 366-271.

Ichniarsyah, A. N., \& Erniati. (2020). The Role of Mechanization in Agricultural Development on Border Areas. In IOP Conference Series: Earth and Environmental Science, 542(1).

Moordiani, R., Wildani, A., \& Widayani, S. (2018). Analisis Kebutuhan Penyuluh Pertanian Mendukung Jawa Tengah Menjadi Lumbung Pangan Nasional. Prosiding Seminar Nasional Fakultas Pertanian UNS, 2(1): C-53.

Nisak, Z. (2013). Analisis SWOT untuk Menentukan Strategi Kompetitif. Jurnal Ekbis, 9(2): 468-476.

Pasandaran, E., Ananto, E.E., Suradisastra, K., Saad, N.S., \& Irawan B. (2014). Sumber Inspirasi Membangun Kemandirian Pangan Pulau-pulau Kecil dan Wilayah Perbatasan. Jakarta: IAARD Press.

Pusat Data dan Sistem Informasi Pertanian. (2018). Statistika Ketenagakerjaan Sektor Pertanian Tahun 2017 - 2018. Kementerian Pertanian.

Putri, N. E., Astuti, R., \& Putri, S. A. (2014). Perencanaan Strategi Pengembangan Restoran Menggunakan Analisis SWOT dan Metode QSPM (Quantitative Strategic Planning Matriks) (Studi Kasus Restoran Big Burger Malang). Industria: Jurnal Teknologi dan Manajemen Agroindustri, 3(2): 93-106.
Rangkuti, F. (2005). Analisis SWOT Teknik Membedah Kasus Bisnis. Jakarta: Gramedia Pustaka Utama.

Setyorini, H., \& Santoso, I. (2017). Analisis Strategi Pemasaran Menggunakan Matriks SWOT dan QSPM (Studi Kasus: Restoran WS Soekarno Hatta Malang). Industria: Jurnal Teknologi dan Manajemen Agroindustri, 5(1): 46-53).

Susilawati. (2016). Teknologi Anjuran Spesifik Lokasi dan Dukungan Upaya Pencapaian Produksi Padi di Kalimantan Tengah. Prosiding Seminar Inovasi Teknologi Pertanian: 350-358.

Tarigan, H. (2019). Mekanisasi Pertanian dan Pengembangan Usaha Pelayanan Jasa Alsintan (UPJA). In Forum penelitian Agro Ekonomi, 36(2): 117128.

Wardani, I. K., \& Erniati. (2020). Strategic Management in The Business of Agricultural Equipment and Machinery Services in Bandung, West Java. IOP Conference Series: Earth and Environmental Science, 542(1).

Wijaya, A. K., Noor, M., \& Surya, I. (2018). Strategi Dinas Pertanian, Perkebunan, Dan Kehutanan Dalam Meningkatkan Produktivitas Pertanian di Kelurahan Tani Aman Kecamatan Loa Janan Ilir Kota Samarinda. Journal Ilmu Pemerintahan, 6(2): 737-748. 